- Field Note -

\title{
Red Oil Palm Cultivation in Little Andaman of Bay of Bengal
}

\author{
T. C. KharTi J. N. Government College, Port Blair - 744104, Andamans, India.
}

\begin{abstract}
Little Andaman is a small island among the islands of the Andaman and Nicobar islands, a Union Territory of India with geographical area of 73440 ha. The climatic conditions of this island is best suited for red oil palm plantation having annual rain fall of $3500-4000 \mathrm{~mm}$ and temperature between $22^{\circ} \mathrm{C}-35^{\circ} \mathrm{C}$ having $5-7$ hours sun shine. In 1979, a project of raising red oil palm plantation over $2400 \mathrm{ha}$, was sanctioned and the job was entrusted to the Andaman and Nicobar Forest and Plantation Development Corporation. A Tenera seeds were imported from different countries and plantation raised from 1973-86 over an area of 1593 ha. N, P, K, Mg fertilizers used in ratio of 7: 7: 14: 7. In 1981 red oil palm was harvested, but the fruits could not processed due to the absence of factory. In 1983 oil extraction press was installed and a regular processing started in 1984 on wards. A pollinating weevil (Elacidobius kamerunicus) was introduced for efficient pollination in September 1986. Rat, rhinoceros beetle, nettle caterpillar, etc gave the common damage to the palm. To control the rodents, owls were introduced in the plantation in 1991. Parakeets also damage the half ripen fruits. Apart from common diseases of red oil plantation, rot spoil the fruits and bunches. Fungus mycelium attacks the bunch and spoils it. Seeing the adverse impact of red palm oil plantation in the Little Andaman, the India Government has withdrawn the further extention of plantation in different islands of the Andaman and Nicobar islands.
\end{abstract}

Key words: India / Bay of Bengal Islands / Liltle Andaman red oil palm cultivation / production / diseases / environmental impact

The Andaman and Nicobar Islands comprising of nearly 572 islands, rocks scattered over $800 \mathrm{~km}$ in the Bay of Bengal at $92^{\circ}$ to $94^{\circ} \mathrm{EL}$ and $6^{\circ}$ to $14^{\circ} \mathrm{NL}$ ( Fig. 1 ). These islands with humid tropical climate are the most suited place in India for oil palm plantation as these islands gets both south-west and northeast monsoon. The soil, generally, are cla y loam, rich in humus. The Andaman and Nicobar Forest Plantation Development Corporation (ANFPDC) has raised oil palm by clearing the original forest on the site. Oil palm cultivation was started in Little Andaman in 1975 and till 1993, the area under plantation is 1593 ha (gross area).

Little Andaman is a small island having total geographical area of 73440 ha. About one third area in the central part of the islands is highly undulating. The area towards south bay is having reserved forest with an aboriginal tribe 'The Ongies'. The eastern part of the island is used for agriculture (Fig. 2). The island harbour many interesting endemic flora and fauna with an indispensable germ palm.

The annual rainfall is 3500 to $4000 \mathrm{~mm}$. Temperature ranges between $22^{\circ} \mathrm{C}$ to $33^{\circ} \mathrm{C}$, sun shine hours are 5 to 7 hours in all months. The above climatic conditions are meeting the required conditions for palm oil plantation. The only unfavourable factor is 3 months dry spell from February to April, which can be made favourable to a great extent with the measures of soil conservation. The soil of Little Andaman is slightly acidic with a pH ranging from 5.5 to 6.5 under natural forest, which is suitable for plantation. 
actually yields the palm oil. The kernel on processing yields kerneloil.

On an average, by weight, FFB yields about $20 \%$ palm oil and $2.5 \%$ of kernel oil. The estimated yields of $\mathrm{FFB}(\mathrm{Mt} / \mathrm{ha})$ worked out on the age of the plantation recorded from 5 th year planting are as follows: 2 in 1st year, 5 in 2nd year, 8 in 3 rd year, 10 in 4 th year, and 15 in 5 th year.

\section{Pests of plantation}

In Little Andaman, field rat, rhinoceros beetle, nettle caterpillar etc. give the damage to the oil palm. Rodents were successfully controlled with the application of rat baits. It is observed that non-coagulant type of rodenticides are better received by rodent population and percentage of killing is much better than that of with coagulant type of rodenticide. The rodents were also controlled through biological control method. Owls were introduced in the plantation in 1991 to control rats with success. Rhinoceros beetle also cause damage to the oil palm trees, if the beetle is not controlled in time the secondary infection with bud rots starts under the high rainfall condition and thereby kills the palms in most cases. Control of rhinoceros beetle manually has not proved to be very successful. Recently, Bucculo virus which causes fatal disease with rhinoceros beetle, which is very specific to it, has been introduce in the plantation with great success. The largest techniques perfected by injecting insecticides directly into the trunk of the tree have been found to be very economical in the control of the nettle caterpillars.

Parakeets in large number invade the plantation and destroy the half ripen fruits completely by devouring the pericarp with their sharp beaks. The fruit bunches are damaged to a great extent and the damaged bunches did not recoup further. Shot guns were used to control the parakeets in the plantation.

\section{Diseases}

Not many of the diseases, which were found in oil palm growing countries of the world, been noticed in the plantation at Little Andaman. Though a score of diseases have been identified by the scientists yet a few of them found to be fatal (Abraham).

Bud rot appears to be caused by infection of the growing tips of the plant through the mechanical damage caused by rhinoceros beetle or the like. If the diseased plant is identified sufficiently, the disease can be controlled by proper fumicide application with the indivisual palm.

Fruit rots or bunch rots are noticed in patches of plantation area where nature fruits are not harvested in time. A lot of unripe fruits in a bunch completely rots with conspicuous bad smell while still on the trees. Mycelium of fungus rotting with the affected fruit bunches are very conspicuous, and the whole bunch is usually lost when affected by the disease. This disease was checked by maintaining good sanitation in the plantation by removing the ripen bunches in the time and frond clearance.

In the nursery, Anthcanose and Cercospora were very conspicuous, which were easily controlled by regular use of proper fungicide. Copper base fungicides were not applied in oil palm plantation or nursery.

\section{Impact of red oil palm plantation on environment}

The agroclimatic conditions which are considered ideally suited for red oil palm cultivation are obtained in the area which are covered by tropical rain forests. These forests are the bastions for gene pool reserves, have a complex ecosystem. Hence, if vast forests of this type are removed to raise oil palm 
plantations, the rich source of germplasm will be lost, so a great care has to be taken before clearing the projects for oil palm plantations.

It is also known that the man power requirement of oil palm plantation is very high and has been estimated at $3.5 \mathrm{men} / \mathrm{ha}$. The high man power requirement in cultivation of palm will cross the carrying capacity of the island adversely affecting the environment, in view of about dangers, the further extension of plantation in different islands of Andaman and Nicobar islands is stopped by government of India.

The adverse effects of the present project on water and air are evident. A stream, Krishna nalah receiving effluents from the mill is highly polluted. Out of 400 labours employed in the project $50 \%$ are suffering from epidemics, drinking water from the same nalah. In a recent survey, many cases of tuberclosis are recorded by the health department from the island. The oil mill is posing health hazards in the vicinity of the mill. No, measures so far has been taken by the concerning authorities to check water and air pollution.

\section{REFERENCES}

Abraham, V. K. Oil palm cultivation in India. Strategy for future development. Oil palm. Report. 30 pp.

Director. 1989. Prospects of oil palm cultivation in Andaman and Nicobar islands. An interm report.

CARI, Port blair. 29 pp.

Nair, M. K. \& Nampoothiri, K. V. K. (Ed.). 1992. Oil Palm Production Technology. Central Plantation

Crops Research Institute, Kasarkod, Kerala, India. 9 pp.

1988a. Oil Palm Cultivation in Andaman and Nicobar islands. Forest Development Corporation

Ltd.,Port Blair. 8 pp.

1988b. Note on Oil Palm Plantation - a Perspective View. ANFPDC Ptd., Port Bair. 18p.

1989. A note on raising of Oil Palm Plantation and Processing of Fruits. ANFPDC Ltd., Port Blair. 29 p.

Received June 1, 2001

Accepted Feb. 10, 2002 